\title{
USURY IN THE INFERNO: AUDITING DANTE'S DEBT TO THE SCHOLASTICS
}

\author{
Simon Ravenscroft ${ }^{*}$
}

\begin{abstract}
There is a close connection between Dante's portrayal of usury in the Inferno and wider scholastic argumentation on the subject. Reading Dante's account in light of the scholastic critique of usury reveals a conceptual depth and clarity to the former which has, in the absence of such a reading, remained unfortunately opaque. Dante's treatment is informed by three of the four main scholastic arguments against usury, which are centered around the themes of the nature and purpose of money, the relation between labor and a just recompense, and the medieval vision of society as an harmonious whole. Each of these themes are weaved by Dante into his poem in a range of diverse ways, yet the final (social) element is arguably a unifying factor. In this regard, his account of usury can be read in continuity with other critiques of 'bad commerce' which are in evidence throughout the Inferno.

Key Words: Dante Alighieri, Inferno, Divine Comedy, scholasticism, scholastic economics, usury, medieval usury prohibition, economic history, medieval theology, medieval literature.
\end{abstract}

\section{INTRODUCTION}

As Joan Ferrante has shown, Dante's Commedia is not a poem of merely moral, religious and literary importance, but also of great political, social and economic depth and resonance. ${ }^{1}$ One key economic aspect of Dante's masterpiece that has yet to be properly explored, however, is the relationship between his treatment of usury in the Inferno and wider scholastic teaching on that subject. The scholastic understanding of usury formed part of the complex and richly integrated theological and political context within which the Commedia first appeared, and it is only in light of this contextual background that many aspects of Dante's poem become properly intelligible. This is indeed the case with his treatment of usury, of which only a superficial understanding can be established without reference to the scholastic teaching. At least, this is the basic premise of this article, which takes on the task of reinterpreting Dante's account of usury in light of the scholastic understanding of that topic. Dante's portrayal of usury in fact evinces substantial indebtedness to three of the four main scholastic arguments against usury. He draws in particular on critiques focused around the themes of the nature of money, of labor and industry, and of social justice and social harmony. Dante creatively re-renders the various scho-

\footnotetext{
* Peterhouse, University of Cambridge, Cambridge, UK, CB2 1RD, srr33@cam.ac.uk.

${ }^{1}$ Joan M. Ferrante, The Political Vision Of The Divine Comedy (Princeton 1984).
} 
lastic arguments in these areas in narrative-poetic form, ultimately offering a nuanced and well-rounded critique of usury, in continuity with wider scholastic economic theory. In elucidating this point, the article contributes to the field by bringing into relief a further aspect of political, social and economic complexity in the Commedia.

The study begins in part one by setting a context. After introducing the scholastic analysis of usury and then evaluating briefly the current state of Dante scholarship on this subject, the economic and historical background to Dante's treatment is then outlined in concise fashion. Part two of the essay is divided into four sections. Each of the first three begin by summarizing a particular scholastic argument against usury, before evaluating an aspect of Dante's portrayal in light of that. The aim here is twofold: first, to reveal the poet's intellectual indebtedness to the scholastic understanding of usury; and second, to illuminate the multi-layered depth and complexity of Dante's own treatment when read against this background. The final section of part two identifies the social aspect of Dante's account as the unifying factor which holds his portrayal together. Read in this way, his treatment of usury appears in continuity with other critiques of 'bad commerce' in evidence throughout the Inferno, and is also contrastable with an alternative social and economic framework laid out especially clearly in certain sections of the Purgatorio. Critical conversation with various Dante commentators and scholars, both contemporary and historical, is maintained throughout, so as to establish the place of the present interpretation in relation to the wider field.

It should be noted that the elements of Dante's portrayal of usury discussed below have been chosen selectively, due to their correspondence with scholastic teaching. While this is certainly a comprehensive treatment, it may not be considered exhaustive of every interpretive angle that could be taken regarding usury in the Inferno. ${ }^{2}$ Furthermore, given the limited length of this study, the analysis remains mostly internal to the Inferno, only exploring in passing connections with the second and third part of the Commedia, or other of Dante's works.

\footnotetext{
${ }^{2}$ There is no discussion, for instance, of what Freinkel has termed Dante's "usurious" use of language; Lisa Freinkel, "Inferno \& The Poetics Of Usura," Modern Language Notes 107.1 (1992) 1-17.
} 


\section{PART 1. GROUNDWORK}

\subsection{INTRODUCTORY REMARKS}

As has commonly been documented, for example by Noonan, Langholm and Wood, ${ }^{3}$ the scholastics deployed four primary arguments against usury. The first was based on a particular view of money; another was an argument from time; another came from a concern for labor and industry; and a fourth was a more general social justice argument arising out of Christian charity and virtue. These arguments are inter-related and, as exemplified by Dante himself, several were often deployed together by theological thinkers, even though, as Wood explains, they seem to have emerged at different times. ${ }^{4}$ The case from money has an Aristotelian heritage (though later received a Thomistic twist), and the fourth "social justice" argument has roots in the preScholastic Christian tradition, most notably the teaching of the patristics. ${ }^{5}$ It is therefore only the time and labor arguments that seem to be distinctively scholastic.

As for Dante, the majority of scholarship addressing his treatment of usury pays inadequate attention to this scholastic context. I argue below that Dante clearly draws on three of the four scholastic arguments mentioned above, the only omission being the time argument. Where commentators do refer to these scholastic critiques, and many do not, ${ }^{6}$ this is rarely in any comprehensive manner. Cherchi, for example, conflates Dante's treatment solely with Aquinas's argument from money, when in truth Dante's analysis is much broader, taking in also the labor and social justice arguments. ${ }^{7}$ Freinkel mentions only Gratian and Aquinas, and again only the argument from money. ${ }^{8}$ Triolo identifies

3 John T. Noonan, The Scholastic Analysis Of Usury (Cambridge, MA 1957); Odd Langholm, Economics In The Medieval Schools: Wealth, Exchange, Value, Money And Usury According To The Paris Theological Tradition, 1200-1350 (New York 1992); Diana Wood, Medieval Economic Thought (Cambridge 2002).

${ }^{4}$ Wood, Medieval Economic Thought (n. 3 above) 159-180.

${ }^{5}$ Robert P. Maloney, "The Teaching Of The Church Fathers On Usury: An Historical Study On The Development Of Christian Thinking," Vigiliae Christianae 27.4 (1973) 241-265.

${ }^{6}$ Scott's analysis stays internal to the Inferno; John A. Scott, "Canto XIV: Capaneus And The Old Man Of Crete," Lectura Dantis: Inferno, ed. Allen Mandelbaum, Anthony Oldcorn, and Charles Ross (London 1998) 186-187. De Gennaro deals briefly with usury but without reference to scholastic sources; Angelo A. De Gennaro, The Reader's Companion To The Divine Comedy (New York 1986) 47.

${ }^{7}$ Paolo Cherchi, "Geryon's Downward Flight; The Usurers," Lectura Dantis: Inferno (n. 6 above) 231-233

${ }^{8}$ Freinkel, "Inferno And The Poetics Of Usura" (n. 2 above) 10. 
scholastic teaching en masse with a social justice argument which interprets usury as a "sin against one's neighbor." Ferrante's analysis is much more thorough, contextualizing well Dante's position on commerce with copious references to church councils and theologians. ${ }^{10}$ Even these references, however, are somewhat ad hoc, and rarely deal with the scholastic argumentation in itself; she seems to omit the laborbased critique entirely, for instance. Dante is sometimes mentioned by economic historians when discussing usury, but this is generally in passing or as a novelty, rather than as a matter of serious analysis. ${ }^{11}$ One explanation for this apparent lacuna in scholarship on the Inferno is the gulf between the two fields. Literary scholars are generally not experts in medieval economic history, while economic historians are rarely inclined towards interpretive studies in poetic literature. Furthermore, it is not immediately evident that Dante even draws on scholastic arguments against usury. This has rather to be drawn out from the text, as the following study illustrates. Before embarking on such an exposition, however, it is helpful to begin by setting the economic and historical context for Dante's writing, in order to understand the background against which his treatment becomes intelligible.

\subsection{ECONOMIC CONTEXT: Usury IN THE SCHOlastic PERIOD}

As becomes clear below, Dante goes to some lengths to depict the wrongful nature of usury, and in so doing borrows from a number of scholastic justifications for the usury prohibition. Lacking from his treatment, however, is any indication of how usury was defined at the time. This itself is a complex question. As Elaine Tan has argued, the notion, common among some economic and legal historians, that usury laws took the form of a static and unsophisticated blanket ban on all lending at interest is deeply reductive. ${ }^{12}$ Rather, "the regulations took centuries to evolve and refine." ${ }^{.13}$ Diana Wood presents a similarly complex picture, charting the revisions and progressions of the medie-

\footnotetext{
${ }^{9}$ Alfred A. Triolo, "Canto XI: Malice And Mad Bestiality," Lectura Dantis: Inferno (n. 6 above) 154-155. As we see below, this leads to a misunderstanding of Dante's use of the labor argument.

${ }^{10}$ Ferrante, Political Vision (n.1 above) 311-379.

${ }^{11}$ See, for example, Wood, Medieval Economic Thought (n. 3 above) 169-170; Will Fisher, "Queer Money," English Literary History 66.1 (1999) 14.

${ }^{12}$ Elaine S. Tan, "An Empty Shell? Rethinking The Usury Laws In Medieval Europe," The Journal Of Legal History 23.3 (2002) 177-179.

${ }^{13}$ Ibid. $177-178$, cf. 187.
} 
val canon law in some detail. ${ }^{14}$ Four key points regarding the legal substance of the usury prohibition will suffice to set the scene for the remainder of this essay.

Firstly, regarding a rudimentary definition, there was both a private and a public element to usury, or in less modern terms, a sin of intention and a sin of action. The former concerned the "sinful hope" by a lender of receiving back more than was given; ${ }^{15}$ the latter can be simply stated as "the act of receiving more than the principal in a loan". ${ }^{16}$ This initial definition must immediately be qualified by noting that the usury prohibition applied only to one kind of loan, the mutuum, where ownership of goods definitively changed hands (what was mine-meum, became yours-tuum). ${ }^{17}$ Even with the mutuum, however, numerous "just titles" to interest became established over time which permitted a return on a loan above the principal. These were many and varied, but applied, for example, when the lender had incurred costs (the title: damnum emergens); when he had foregone some clear profit-making venture to make the loan (lucrum cessans); when a borrower was guilty of late repayment (poena detentori); or when the lender somehow shared risk with the borrower. ${ }^{18}$ These titles were often a matter of controversy among theologians. Aquinas, for instance, rejected the validity of the lucrum cessans title, but defended damnum emergens style arrangements. ${ }^{19}$ Significantly, though, such qualifications of the usury prohibition had nothing to do with the rate of interest being charged, but concerned the nature and circumstances of the loan in question. As such, without a valid title, a lender who charged any interest above the principal was guilty of usury, regardless of whether the rate was low, mod-

${ }^{14}$ Wood, Medieval Economic Thought (n. 3 above) 159-205.

${ }^{15}$ Ibid. 160; cf. Noonan, Scholastic Analysis Of Usury (n. 3 above) 18.

${ }^{16}$ Tan, “An Empty Shell?” (n. 12 above) 177.

17 Wood, Medieval Economic Thought (n. 3 above) 186; Raymond De Roover, "The Scholastics, Usury And Foreign Exchange," The Business History Review 41.3 (1967) 257-271. While the usury prohibition primarily concerned money loans, it could also be applied to anything that could be weighed, measured, or counted; cf. Wood (n. 3 above) 160. Change of ownership was vital because risk passed with ownership.

${ }^{18}$ Tan, "An Empty Shell?" (n. 12 above) 180ff; De Roover, "The Scholastics, Usury And Foreign Exchange" (n. 17 above) 261ff; D. Stephen Long, "Bernard Dempsey's Theological Economics: Usury, Profit And Human Fulfilment," Theological Studies 57 (1996) 695ff. Various contracts, such as the sea loan, or the societas (partnership) arrangement applied here.

${ }^{19}$ Thomas Aquinas, Summa Theologica, II-II.78.2.1; cited from The Summa Theologica Of St. Thomas Aquinas, 2nd rev. ed., trans. the Fathers of the English Dominican Province (1920); sourced from http://www.newadvent.org/summa/. 
erate or high. ${ }^{20}$ Finally, a key point to make is that the usury prohibition, as outlined above, was primarily a matter for ecclesiastical law and ecclesiastical courts. The various forms of civil law that were in place across Christendom were generally more accommodating of (what the church would consider) usurious practice, often outlawing only the worst excesses. ${ }^{21}$ These legal variations and technicalities are not addressed as such by Dante, but do form an important part of the background against which his treatment is better understood.

\subsection{Historical Context: Medieval Florence}

Jeremy Catto has asserted that, "To the modern observer, the world of Dante must be seen through the eyes of Florentine civilization." 22 As such, it is important to set a brief historical context prior to embarking on the main portion of the essay. Florence, frequently the butt of Dante's wrath in the Inferno, was a thriving centre of commerce and mercantile trade in the scholastic period. ${ }^{23}$ As Dante himself declares sardonically, however, this success was not built on virtue:

Godi, Fiorenza, poi che se' sì grande

che per mare e per terra batti l'ali,

e per lo 'nferno tuo nome si spande!

(Be joyful, Florence, since you are so great

that your outstretched wings beat over land and sea,

and your name is spread throughout the realm of Hell! $)^{24}$

Dante frequently chastises the Florence of his day for the pride, unrestraint and avarice that has resulted from their "sùbiti guadagni" (sudden

\footnotetext{
${ }^{20}$ De Roover, "The Scholastics, Usury And Foreign Exchange" (n. 17 above) 258; Noonan, Scholastic Analysis Of Usury (n. 3 above) 400.

${ }^{21}$ Wood, Medieval Economic Thought (n. 3 above) 172; Joseph Burke, "Usury Redux: Notes On The Scholastic Analysis Of Usury By John T. Noonan,” Department Of Economics Working Paper No. 0901 (Ave Maria University 2009) 10. It's generally accepted, though, that ecclesiastical courts themselves became increasingly lenient towards the end of the middle ages; see, e.g., Tan, "An Empty Shell" (n. 12 above) 191ff.

${ }^{22}$ Jeremy Catto, "Florence, Tuscany And The World Of Dante," The World Of Dante: Essays On Dante \& His Times, ed. Cecil Grayson (Oxford 1980) 1.

${ }^{23}$ Ibid. 1-18; Anthony J. De Vito, "Dante's Attitude Toward The Italian Cities In The Divine Comedy," Studies In Philology 48.1 (1951) 1-14.

${ }^{24}$ Dante Alighieri, Inferno, XXVI:1-3; Italian cited from The Divine Comedy: Inferno, ed. Charles S. Singleton (Princeton 1980); English translations are taken from Dante: The Divine Comedy, Volume 1: Inferno, trans. Mark Musa (London 1984).
} 
wealth). ${ }^{25}$ Regarding usury in particular, moneylending for profit by rich Florentine banking families was certainly well instituted in Dante's time. ${ }^{26}$ According to Catto, "The bankers of Florence had established, by 1300 , an astonishingly precocious system of international credit.", 27 Dante was surely aware of this, as he makes the vast majority of usurers in his Inferno Florentine, such that one unnamed usurer (the only one to speak) comments, "Con questi Fiorentin son padoano" (Among these Florentines I sit, one Paduan).$^{28}$ Even allowing for some mild exaggeration by this proud and probably rivalrous native of Padua, one receives the impression that the vast number of Dante's usurious "crowd" are indeed Florentine. ${ }^{29}$ Florence, furthermore, provides an illustration of that "flexibility" of civil usury laws mentioned above. According to Becker, civil leaders in Florence were so prejudiced by the need to protect their economic interests, that ordinances against usury were applied only to pawn-brokers and not, significantly, the wealthy Florentine merchant-princes, whose money-lending activities continued without formal censure from the city. ${ }^{30}$ Such malpractice, as Becker suggests, will have provided Dante with ample motivation for his severe treatment of Florentine decadence and wealth throughout the Inferno.

Part 2. Dante's Treatment of Usury In Scholastic ConteXt Against this historical and economic background, therefore, Dante chose to portray usury in a particular way in his Inferno. As with everything else in his poem, it can be assumed that this is done deliberately and purposively. The remainder of this essay examines the character of his treatment, and seeks to discover the intellectual "debts" Dante himself owed to the scholastic teaching on the subject.

\footnotetext{
${ }^{25}$ Dante, Inferno (n. 24 above) XVI:73-75, XV:68; cf. De Vito, "Dante's Attitude Toward The Italian Cities" (n. 23 above) 8.

${ }^{26}$ Joan M. Ferrante, "Hell As The Mirror Imagine Of Paradise," Inferno: The Indiana Critical Edition, ed. Mark Musa (Bloomington1995) 375.

${ }^{27}$ Catto, "Florence, Tuscany And The World Of Dante" (n. 22 above) 12.

${ }^{28}$ Dante, Inferno (n. 24 above) XVII:70.

${ }^{29}$ Ibid. XVII:58. For details of the various families identified by Dante here, see Mark Musa, "Introduction, Notes and Commentary," Dante: The Divine Comedy, Volume 1: Inferno, trans. Mark Musa (n. 24 above) 229.

${ }^{30}$ Marvin B. Becker, "Dante And His Literary Contemporaries As Political Men," Speculum 41.4 (1966) 678; Benjamin N. Nelson, "The Usurer And The Merchant Prince: Italian Businessmen And The Ecclesiastical Law Of Restitution, 1100-1550," The Journal Of Economic History 7, Supplement (1947) 104-122.
} 


\subsection{THE MONEY ARGUMENT}

Aristotle stated that "of all modes of acquisition, usury is the most unnatural." 31 His argument had two sides. Firstly, money exists fundamentally to facilitate exchange, and therefore to treat it as a source of profit in itself is to contradict its proper $\tau \varepsilon \lambda{ }^{\circ} \varsigma$ (telos: end). Secondly, unlike livestock or fruit trees for example, money is sterile and if stored does not naturally fructify. In both cases, the practice of making profit from money alone, or of "breeding" money from money, is objectionable, as it takes the "wrong amount from the wrong source." 32 Many of the scholastics, most notably Aquinas, adopted these arguments and added to it a further claim, related to money's essential nature as fungible. Citing Aristotle, Thomas states, "the proper and principal use of money is its consumption or alienation whereby it is sunk in exchange." ${ }^{33}$ As essentially a means of exchange, money is consumed in use, that is, in and through the very act of exchange, and in this regard Aquinas likens it to wine or wheat, which are also consumed in use. Its ownership cannot be separated from its use as a means of exchange, but rather, "its very essence coincides with its use." 34 Aquinas contrasts money with a durable good like a house or a silver vessel, which performs a service. ${ }^{35}$ With the latter it is possible to rent out the use of the good while still retaining its ownership, and therefore it is reasonable to make a charge for such use. This is not possible with money because when a lender makes a money loan, he must according to this logic transfer ownership of that money to the borrower, who subsequently uses it up in consumption or exchange. ${ }^{36}$ While the lender can expect restitution equal to the amount lent, as he would if he lent a quantity of grain or wheat, he cannot also charge for the use of the money, as such use is inseparable from the money's

\footnotetext{
${ }^{31}$ Aristotle. Politics, I:1258a; cited from The Politics, trans. E. Barker (Oxford 1995).

${ }^{32}$ Aristotle, Nicomachean Ethics, IV:1122a; cited from Nichomachean Ethics, trans. T. Irwin (Cambridge, MA 1999). Cf. Scott Meikle, "Aristotle And The Political Economy Of The Polis," The Journal Of Hellenic Studies 99 (1979) 62-63. Money is here seen merely as a store of value which neither increases nor diminishes, neither fructifies nor rots.

${ }^{33}$ Aquinas, Summa (n.19 above) II-II:78.1.

${ }^{34}$ Cherchi, "Geryon's Downward Flight" (n.7 above) 231.

${ }^{35}$ Aquinas, Summa (n.19 above) II-II:78.1.6; cf. Ernesto Screpanti and Stefano Zamagni, An Outline Of The History Of Economic Thought, trans. David Field (Oxford 1995) 18.

${ }^{36}$ Note how this logic accords with restricting the usury prohibition to the mutuum loan, where what is mine (meum) becomes yours (tuum).
} 
ownership, and is therefore "to sell what does not exist." summary, usurious lending contradicts the nature of money as sterile, making it "breed" unnaturally, and as fungible and consumed in use, artificially separating its ownership from its use, and also contradicts the principal telos of money, to facilitate exchange and trade, as it turns money into a means of profit in itself. According to all of these lines of reasoning, usury is seen to run counter to nature.

Dante appears to draw on these arguments from the nature of money when he links usury with the sins of blasphemy and sodomy in the final section of hell's seventh circle. These three sins are located together as sins of violence against God, and they are all punished in like manner, the perpetrators suffering from burning sand beneath them and a rain of fire falling from above. ${ }^{38}$ Dealing with the connection between sodomy and usury first, the relationship is one of inversion, as for Dante, sodomy is the making sterile of that which is naturally productive (the sexual act) ${ }^{39}$ whereas in contrast, usury is the making productive of that which is naturally sterile (money). Or, as Fisher puts it, "Whereas the usurer attempts to consume a barren thing and thus make it nourishing, the sodomite consumes a potentially productive thing, thereby making it barren., ${ }^{, 0}$ This reasoning is clearly dependent on the sterility argument cited above for its cogency, as the contrast with sodomy is effective only insofar as money is viewed as naturally unfruitful, and as having a non-productive end (exchange) ${ }^{41}$ The two sins, staged in this way, are a kind of inversion of one another; they are both unnatural, and are both teleologically misdirected, but in opposite ways - two opposite sides of the same coin, as it were. This dual-relation of difference and sameness in the sodomy/usury dynamic may be why Dante portrays the sodomites as engaged in perpetual wandering, while the usurers are crouched and still, ${ }^{42}$ even though the two yet suffer the

${ }^{37}$ Aquinas, Summa (n. 19 above) II-II:78.1; cf. Wood, Medieval Economic Thought (n. 3 above) 161 . low.

${ }^{38}$ Dante, Inferno (n. 24 above) XIV:13-42. This shared contrapasso is discussed be-

${ }^{39}$ Sodomy viewed here as "unnatural" sexual behavior, that is, any sexual act not orientated to its proper end of reproduction (another teleological argument).

${ }^{40}$ Fisher, "Queer Money" (n. 11 above) 14; cf. Cherchi, "Geryon's Downward Flight" (n. 7 above) 232 .

${ }^{41}$ Of course, the practice of trade and exchange can be productive and profitable (see below), but according to the scholastics not money per se.

${ }^{42}$ Dante, Inferno (n.24 above) XIV:23-24. The "stillness" of the usurers may also reflect the fact that they make their profit without labor (see below). 
same punishment, and (upon closer inspection) respond similarly by hurriedly and incessantly brushing off the falling flames with their hands. ${ }^{43}$ By relating the two sins in this way, however, Dante reveals his indebtedness to this area of scholastic teaching.

The relationship of usury to blasphemy provides further evidence of this debt. It is relevant to note, first, that the identification of these two sins sits against a background of a broader link between the misuse of money and the misuse of language in the Inferno. ${ }^{44}$ For example, Ferrante notes that the earliest instance of "gibberish" in hell occurs in canto VII out of the mouth of Plutus, the god of wealth, ${ }^{45}$ and that in the same canto, hell's first economic sinners (the prodigal and the miserly) attack each other with words, or "s'incontran con sì aspre lingue" (come to blows with harsh refrains). ${ }^{46}$ Another example is the close identification of deceivers and counterfeiters at the bottom of circle eight, where the liar Sinon says to the counterfeiter Adam: "S'io disso falso, e tu falsasti il conio" (My words were false-so were the coins you made). ${ }^{47}$ That the abuse of money and language are related, however, is because they are both "a basic instrument of exchange." ${ }^{, 8}$ Both language and money can be put to good, constructive social use, or to various forms of misuse. Indeed, often the misuse of language, such as in the deception necessary for betrayal or fraud, is motivated by the desire for illicit monetary gain, as exemplified far down in Cocytus where is found Judas, who betrayed Christ for thirty pieces of silver. ${ }^{49}$ This wider background forms part of the context for Dante's identification of usury with blasphemy.

\footnotetext{
${ }^{43}$ Ibid. XIV:40-42, XVII:46-51.

${ }^{44}$ Ferrante, Political Vision (n. 1 above) 311-379; Joan M. Ferrante, "The Relation Of Speech To Sin In The Inferno," Dante Studies 87 (1969) 33-46; Freinkel, "Inferno And The Poetics Of Usura" (n. 2 above) 1-17.

${ }^{45}$ Dante, Inferno (n. 24 above) VII:1-3. Plutus ultimately cannot respond to Virgil's proper use of language and, as Ruskin noted, "literally 'collapses' at a word"; John Ruskin, "Unto This Last," John Ruskin: Unto This Last And Other Writings, ed. Clive Wilmer (London 1997) 219.

${ }^{46}$ Dante, Inferno (n. 24 above) XI:72 cf. VII:30. Ferrante, Political Vision (n. 1 above) 325 .

${ }^{47}$ Ibid. XXX:115. It may be telling in this regard that the only usurer who addresses Dante in hell does so angrily, and then goes on to slander another of his kind; ibid. XVII:66-73.

${ }^{48}$ Ferrante, Political Vision (n. 1 above), 325.

${ }^{49}$ Dante, Inferno (n. 24 above) XXXIV:55ff. Various sins of fraud also illustrate this connection; see, e.g., Ferrante Political Vision (n. 1 above) 324-328.
} 
In addition to exchange, a further purpose of language for Dante, as frequent passages in the Purgatorio illustrate, is doxology. ${ }^{50}$ It is especially this end which blasphemy, the cursing of God, subverts. As blasphemy is a corrupted misuse of language, or language separated from its proper doxological end, so usury is a corrupted misuse of money, or money separated from its proper end of facilitating exchange. As with sodomy, therefore, the identification of usury with blasphemy reveals a similar dynamic interplay of difference and (more fundamental) sameness between the two sins. This only becomes intelligible, however, when money is understood teleologically, as having its end not in immediate profit, but in exchange. As shown above, this teleological rendering of money is typically scholastic (albeit with an Aristotelian heritage), forming a fundamental building block of the corresponding critique of usury. Therefore, just as Dante's identification of sodomy and usury reveals a debt to scholastic argumentation, the identification of blasphemy with usury reveals the same. All three sins share the same deviant trait: they subvert their proper teleological ends, and this makes them unnatural. Blasphemers subvert the doxological end of language by cursing God; sodomites subvert the reproductive end of the sexual act by making it sterile; usurers subvert the proper end of money as a means of exchange, by making it "grow," or yield artificial profits, of itself.

The inversion of nature which characterizes these three sins can be read into the shared contrapasso of the perpetrators, as Scott suggests. ${ }^{51}$ Fire, which naturally rises upwards ${ }^{52}$ here falls from the sky; the earth, which is naturally fertile and bears fruit after receiving rainfall, is here arid burning sand, receiving a destructive rain of fire. Understood in these terms, the contrapasso is an analogy of the essentially anti-telic nature of these three sins. Such an explanation is more satisfactory than those offered by Cherchi, De Gennaro, Pequigney, and (over a hundred years ago) by Maria Rossetti. The first three of these focus on one category of sin at the expense of the other two, thereby failing to accommodate the shared nature of this contrapasso. After a detailed analysis

\footnotetext{
${ }^{50}$ Dante Alighieri, Purgatorio, e.g., V:22ff, VI:82ff, VIII13ff, IX:139; Italian source: The Divine Comedy: Purgatorio, ed. Charles S. Singleton (Princeton 1982). Cf. Ferrante, "The Relation Of Speech To Sin" (n. 44 above) 33-46.

${ }^{51}$ John A. Scott, "Canto XIV: Capaneus And The Old Man Of Crete," Lectura Dantis: Inferno (n. 6 above) 186-187.

${ }^{52}$ Dante Alighieri, Paradiso, XXIII:40-42; Italian source: The Divine Comedy: Paradiso, ed. Singleton (n. 50 above).
} 
of sodomy, Cherchi argues that the contrapasso represents the sterility of the three sins, but fails to explain how blasphemy and usury are sterile as sodomy is sterile. ${ }^{53}$ Given what has been said above, it is rather the false productivity of usury which seems to be at issue for Dante, as opposed to any apparent sterility. One could argue in Cherchi's defense that the three sins all result in a "fruitless" or "sterile" life, at least in spiritual terms, but this could be said of any sin in the Inferno, and is therefore too general, failing to account for the specificity of the particular contrapasso in question. Pequigney also focuses on sodomy, and argues that the punishment represents the biblical judgment on Sodom and Gomorrah, and the burning passion of the sodomites. ${ }^{54}$ There is, however, no mention of how this explanation relates to blasphemy or usury. De Gennaro, on the other hand, states that the usurer is punished by fire because "he does not earn money with the sweat of his brow." 55 This, as is discussed below, does indeed form a part of Dante's critique of usury which could be referred to obliquely here. Again, though, De Gennaro fails to expand this explanation to include also the blasphemers and sodomites. Rossetti's much broader analysis is, in contrast, initially more convincing. She makes an interesting connection between the fiery rain and a passage in the Convivio where Dante speaks of virtue raining down in flamelets of fire. ${ }^{56}$ Rossetti suggests that the sinners disregarded this virtuous rain on earth, and so it has "penetrated within the earth to punish them." ${ }^{, 57}$ As creative as this reading is (and notwithstanding that plural interpretations of the contrapasso are surely valid), it is not as satisfying as the explanation advocated here, that the contrapasso analogizes, with some irony, the unnatural and anti-telic character of the three sins in question. This reading fits especially comfortably with the scholastic money-based critiques of usury that priorities the nature and telos of money. For Dante, it seems, as in life the usurers opposed the natural order with regard to money, so in hell the natural order opposes them.

\footnotetext{
${ }^{53}$ Cherchi, "Geryon's Downward Flight" (n. 7 above) 232.

${ }^{54}$ Joseph Pequigney, "Sodomy In Dante's Inferno And Purgatory," Representations 36 (1991) 25.

${ }^{55}$ De Gennaro, Reader's Companion (n. 6 above) 47.

${ }^{56}$ Dante Alighieri, Convivio, III:15.120-130; cited from: The Convivio Of Dante Alighieri, ed. Philip H. Wicksteed (London 1903).

${ }^{57}$ Maria F. Rosetti, A Shadow Of Dante, Illustrated Edition (Whitefish 1998) 54-55.
} 


\subsection{THE TIME \& LABOR ARGUMENTS}

The next scholastic critique that Dante utilizes is that relating to labor. Before addressing this directly, it is worth examining the "time" argument, omitted by Dante, as this forms part of the context for the emergence of the labor critique. The Aristotelian-inspired sterility and fungibility arguments could potentially be side-stepped, if not directly rebutted, with the contention that, even if money cannot naturally fructify, when judiciously invested over time, it can yield profit. ${ }^{58}$ Given that two people cannot use the same money, both at once, a lender could be said to deserve remuneration for the benefit borrowers receive by acquiring, at the lender's detriment, the use of the lent money for the duration of the loan. The key element here is not the use of the money, which Aquinas said was inseparable from its ownership, but the time afforded the borrower to invest the money profitably; that is, the advantage of having the money now and not later, and the detriment to the lender of foregoing that benefit until repayment. In other words, if a lender cannot justly sell money's use, can he not sell time? On the contrary, as Wood states, it was a "medieval commonplace" that time belonged to God, and what belongs to God could not be sold by man. ${ }^{59}$ Thirteenth-century theologian Thomas of Chobham, wrote: "The usurer does not sell the debtor something which is his own, but time, which belongs to God. It follows that because he sells something belonging to another he ought not to have any profit from it." ${ }^{, 60}$ Medieval time was ecclesiastical time, it was regulated by the church calendar and by liturgical seasons, and its passage was marked by the ringing of church bells. Such time could not be owned nor sold by men, for it was the free gift of God to the community. In apparently seeking to profit from the sale of time, therefore, the usurer was deemed to be the thief of both God and the community. ${ }^{61}$ Such an understanding provided further justification for the medieval usury prohibition.

Significantly, though, medieval economic historians have noted a shift in scholastic thinking as the middle ages progressed, from this

\footnotetext{
${ }^{58}$ Cf. Wood, Medieval Economic Thought (n. 3 above) 174ff; D. Stephen Long, "Usury: Avarice As A Capital Vice," Calculated Futures: Theology, Ethics And Economics, ed. D. Stephen Long, Nancy Ruth Fox, and Tripp Yorke (Waco 2007) 144.

${ }^{59}$ Wood, Medieval Economic Thought (n. 3 above) 174.

${ }^{60}$ Thomas Of Chobham, Summa Confessorum, ed. F. Broomsfield (Paris 1968) 504.

${ }^{61}$ Wood, Medieval Economic Thought (n. 3 above) 174; Jacques Le Goff, Your Money Or Your Life: Economy And Religion In The Middle Ages, trans. Patricia Ranum (New York 1990) 33-45.
} 
time argument, to an argument from labor. As Wood explains, "Scholastic thinkers began to realize that it was not actually time that made barren money fertile, but labor and industry." ${ }^{262}$ While the time argument was a useful tool for critics of usurious lending, enabling them to declaim the latter as theft from God, it implicitly undermines the Aristotelian (and subsequently scholastic) view that money is sterile. To suggest that the application of time makes money 'grow' compromises the notion that stored money neither gains nor decreases in value; it is to claim that barren money can indeed fructify over time, and disregards the question of whether it is put to productive use. The labor argument, in contrast, accords much more coherently with the sterility doctrine, as one can still maintain that stored money is barren, while also asserting that the effective application of labor and industry to an investment can and does yield profit, ${ }^{63}$ as indeed Aquinas and others argued. ${ }^{64}$ It is unclear why neither Aquinas nor Dante made use of the time argument, when others such as Thomas of Chobham utilized it together with the labor argument, ${ }^{65}$ but this apparent incongruence with the sterility doctrine may have been a factor (Dante, of course, is likely to have been following Aquinas in this area).

The suggestion that the application of labor can make money yield profit was to raise new questions with regard to the usury prohibition, for whereas in the medieval mind time belonged to God, and could not therefore be made subject to sale and purchase, labor certainly belonged to man. ${ }^{66}$ On one hand, the church's usury laws found ways to allow for the profit-making potential of "money-plus-labor," principally through the societas arrangement. Here it was permitted for one partner to contribute capital and another labor to a joint venture, and as

\footnotetext{
${ }^{62}$ Wood, Medieval Economic Thought (n. 3 above) 177. Wood notes that to the scholastics, "industry appears to mean business acumen, sagacity, even perhaps entrepreneurship, as opposed to manual labour"; ibid. 178.

${ }^{63}$ De Roover suggests, without justification, that these two principles (the labor theory and the sterility doctrine) are at variance, stating that the scholastics repeatedly contradicted themselves in this regard; De Roover, "The Scholastics, Usury And Foreign Exchange" (n.17 above) 260. This seems unfounded, for the reasons outlined above.

${ }^{64}$ Wood, Medieval Economic Thought (n. 3 above) 178-180. Aquinas: “... anything that has been made out of a [fungible] commodity is the fruit, not of the thing itself, but of human industry"; Summa (n. 19 above) II-II:78.3. Richard of Middleton (d. 1302): “... money of itself is a sterile thing, for it can bring forth no fruit except by the labour and solicitude of the user"; cited in Wood, Medieval Economic Thought (n. 3 above) 179 (my emphasis).

${ }^{65}$ Chobham, Summa Confessorum (n. 60 above) 504.

${ }^{66}$ Wood, Medieval Economic Thought (n. 3 above) 177; cf. Genesis $3.17 \mathrm{ff}$.
} 
long as risk was shared between the parties, profits could also be shared, giving a lender the opportunity for a valid return on a money investment, albeit with risk of loss. ${ }^{67}$ On the other hand, a different argument was made against usury with the use of this labor theory. ${ }^{68}$ Referring to the concept of the just wage, Long states that "the scholastics consistently affirmed a connection between one's labor and an appropriate remuneration." ${ }^{69}$ The "work" of the usurer, however, distorts this connection in both directions, decreasing the just wage of the borrower through illicit charges to interest, whilst yielding a wage for the usurer which, in the absence of labor and industry on his part, must be considered unjust. Usury again appears as a form of theft, but this time from man, of the fruits of his labor. Rather than applying his own labor to money and making just profit through his own exertion, the usurer effectively profits off the labor of another. As such, "The informal definition of usury came to be making a profit without working for it.",70 Gen. 3.17 was often cited as biblical evidence in this regard, as per Thomas of Chobham: "[the usurer] wishes to pursue his profit without any labor, even while sleeping, which is contrary to the precept of the Lord, 'In labor and the sweat of your face shall you get your bread." "71

With this context in mind, even a cursory look at canto XI makes it clear that Dante knew of, and drew from, this labor argument. In lines 94-6 of this canto, the Pilgrim asks for clarification as to how "ch'usura offende la divina bontade" (usury offends God's goodness). ${ }^{72}$ Virgil first proceeds, citing Aristotle, to describe how human "art" (see below) is "a Dio quasi è nepote" (as it were, God's grandchild), as it is

\footnotetext{
${ }^{67}$ Tan, “An Empty Shell?” (n. 12 above) 185; Long, "Bernard Dempsey’s Theological Economics" (n. 18 above) 695; de Roover, "The Scholastics, Usury And Foreign Exchange" (n. 17 above) 260. Such an arrangement avoided the usury prohibition insofar as the pooling of assets, meant that this was not a strict mutuum where ownership of money changed hands (along with risk).

${ }^{68}$ This labor theory was famously conflated by R. H. Tawney with the Marxist labor theory of value, Tawney calling Marx the "last of the schoolmen"; cf. Long, "Usury: Avarice As A Capital Vice" (n. 58 above) 145. This is generally taken to be an exaggerative, but not entirely unfounded, claim. Langholm has referred to the scholastic theory more as a "political" (rather than economic) labor theory; Langholm, "Economics In The Medieval Schools" (n. 3 above) 27. There is not space to address this debate here.

${ }^{69}$ Long, "Usury: Avarice As A Capital Vice" (n. 58 above) 145; cf. Luke 10.7.

${ }^{70}$ Wood, Medieval Economic Thought (n. 3 above) 174, cf. 177.

${ }^{71}$ Chobham, Summa Confessorum (n. 60 above) 504.

${ }^{72}$ Dante, Inferno (n. 24 above) XI:95-96 cf. XI:46-51.
} 
the child of nature, which is the child of God. ${ }^{73} \mathrm{He}$ then explains the following, and it is worth quoting lines 106-111 in full:

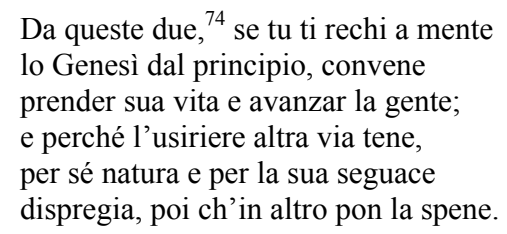

(From Art and Nature man was meant to take his daily bread to live - if you recall the book of Genesis near the beginning; but the usurer, adopting other means, scorns Nature in herself and in her pupil, Art-he invests his hope in something else.)

This, as the gesture towards Genesis makes especially clear (compare Chobham above), is a direct adoption of the scholastic labor critique, but with something of an Aristotelian twist. Dante takes the usual argument, but conflates what the scholastics generally referred to as "labor" or "industry," with what Aristotle called "art." $\tau \dot{\varepsilon} \chi v \eta$ (technē: art, skill, or craft) ${ }^{75}$ for Aristotle, indicates the full range of human makings and productive activities; he refers, for instance, to the "art of acquisition" and the "art of medicine." Physics to which Virgil refers, Aristotle deploys this broad usage, ${ }^{77}$ but also asserts that all human techne imitates nature. ${ }^{78}$ Dante's use of Aristotle here seems primarily rhetorical, nevertheless, with the substance of his argument remaining the same as that of the scholastics: the usurer does not work for his bread, and stands condemned as a result. Dante's reasoning therefore has three steps. First, he contends that nature is the art of God; second, labor, industry, "human makings" in the widest possible sense, are the art of man; third, the usurer scorns the latter, by taking an "unearned increment," and thereby commits vio-

\footnotetext{
${ }^{73}$ Ibid. XI:97-105.

${ }^{74}$ That is, from arte e natura.

${ }^{75}$ Dante would presumably have been using a latin translation, of course.

${ }^{76}$ Aristotle, Politics (n.31 above) 1257b.

${ }^{77} \mathrm{He}$ refers, for example, to "the art which uses the product and the art which directs the production of it." Aristotle, Physics, II.2; cited from Physics, trans. Robin Waterfield (Oxford 2008).

${ }^{78}$ This correlation of art and usury would later become important for Ezra Pound, notably in his poem With Usura (canto 45).
} 
lence against God by deviating from the "divine and natural precept" that man must work for his bread. ${ }^{79}$ As with the scholastic argument, the absence of labor is what makes the usurer's profit unconscionable for Dante.

Despite the clear congruence with the scholastic labor critique of usury, it is hard to find a Dante scholar who acknowledges this debt. For instance, in his detailed commentary on canto XI, Triolo implies that Dante may have developed such an argument himself. He claims that had Dante wanted to follow the tradition, he would have presented usury as a "sin against one's neighbor"; he supposedly chooses against this, however, instead "seeking something more grandiose [and thus] Virgil's argument syllogistically fuses pagan and Judaeo-Christian formulae." ${ }^{80}$ Triolo is obviously referring to Dante's joining of the Genesis reference with Aristotle's account of human art taken from the Physics. While Dante's use of Aristotle is indeed novel in this context, such use of Genesis was, as stated above, a scholastic standard, posited against the background of a well-developed labor-based critique of usury. Far from creating a grandiose fusion of "pagan and Judeo-Christian formulae," Dante is merely adding an Aristotelian flourish to a well-established medieval commonplace. Indeed, as shown above, the fusion of Greek and Christian thought - as might be expected following Aquinas - was already central to the usury critique more generally. Triolo's misunderstanding is therefore predicated on an insufficient knowledge of the scholastic economic theory which clearly informs Dante's treatment. He is not alone, however. Perhaps most surprisingly, Joan Ferrante, in her otherwise excellent study of the political and commercial significance of the Commedia, fails to make any mention at all of the labor critique. ${ }^{81}$ In a later publication this leads her to claim that Dante's decision to locate usury in the circle of violence rather than fraud was his way of taking a more moderate stance on usury than that of the church. ${ }^{82}$ On the contrary, by presenting usury as a sin of violence against art, Dante was really drawing on scholastic teaching to further condemn usury from a different perspective, that of labor and

\footnotetext{
${ }^{79}$ Triolo, "Canto XI" (n. 9 above) 155.

${ }^{80}$ Ibid.

${ }^{81}$ Ferrante, Political Vision (n. 1 above).

${ }^{82}$ Ferrante, "Hell As The Mirror Image Of Paradise" (n. 26 above) 375.
} 
industry (without, as is discussed below, entirely severing the connection with fraud) ${ }^{83}$

\subsection{THE SOCIAL ARGUMENT}

As the previous two sections have shown, Dante's treatment of usury fits well against the background of scholastic anti-usury arguments from money and labor. Perhaps the most fundamental of all the scholastic arguments against usury, however, shared with patristic sources, was the notion that usury was a sin against society, constituting an exploitation of the poor, and a practice incompatible with the principal Christian virtue of charity. ${ }^{84}$ Three points are relevant here. Firstly, usury contradicted the medieval principle that "the superfluities of the rich belonged by right to the poor. ${ }^{" 85}$ Rather than giving freely to those in need from their excess, as demanded by Christian charity, usurious lending put the rich in a position to gain from the poor. Thus, William of Auxerre (d. 1231) asserted that usury was "contrary to the species of justice which obliges us to receive a neighbor in need." ${ }^{86}$ Demanding a return above the principal amounted to exploitation because the poor have little choice but to accept the usurer's terms when, due to their need, the borrowing of money constitutes a material necessity. Between the parties there is a clear inequality of bargaining power, to use a contemporary idiom, and Aquinas noted this coercive element in his lengthy treatise on usury in De Malo:

He who pays usury suffers injustice not from himself but from the usurer, for granted that the usurer does not apply absolute force he nevertheless applies a certain mixed force on him, in that the necessity of having to accept the loan imposes a serious condition so that he returns more than he is given. $^{87}$

\footnotetext{
${ }^{83}$ None of the other commentators on usury in the Inferno so far cited reference this scholastic argument either; cf. Cherchi (n. 7 above), De Gennaro (n. 6 above), Freinkel (n. 2 above), Musa (n. 29 above), Pequigney (n. 54 above), Rossetti (n. 57 above), Scott (n. 6 above).

${ }^{84}$ Maloney, "The Teaching Of The Church Fathers On Usury" (n. 5 above) 241-265.

${ }^{85}$ Wood, Medieval Economic Thought (n. 3 above) 164. John Milbank notes that the practice of giving the surplus of public wealth to the needy was enacted in Catholic Spain even into the 18th c., receiving scorn from Scottish political economist James Steuart; John Milbank, Theology And Social Theory, 2nd ed. (London 2006) 31.

${ }^{86}$ Cited in Langholm, Economics In The Medieval Schools (n. 3 above) 77.

${ }^{87}$ Thomas Aquinas, De Malo, XIII.4.7; cited from De Malo, trans. Brian Davies, ed. Richard Regan (Oxford 2001).
} 
In this light, the usurer is guilty of using his position of power (as 'the one with the money') as leverage to extract profit from the poor. Such behavior is the antithesis of charity, for whereas charitable giving is intended to relieve the hardships of the poor, to lend usuriously is rather to increase their needs, by eliciting repayments in excess of what was required to meet their original requirements. ${ }^{88}$ Indeed, this is precisely why Bernadino of Sienna argued that usury was a motor for social inequality, as it "concentrates the money of the community in the hands of a few, just as if all the blood in a man's body ran to his heart and left his other organs depleted." ${ }^{\prime 89}$

Bernadino's body analogy is illustrative, secondly, of the strongly organic view of society which prevailed in the middle ages, and which constitutes the background to this social critique of usury, as it does for Dante's Commedia more generally. Finkelstein and Thimm explain this medieval social philosophy as follows: "Society was conceived as a social organism, akin to the human body, composed of many members, each having different functions but complementing each other in an overall harmony." ${ }^{, 00}$ This harmonious ideal for society—undergirded by a social-ontological vision of "hierarchical complementarity," to use Taylor's phraseology ${ }^{91}$ —was undermined by usury, because those who practiced the latter sought to benefit themselves at the expense of their neighbors, and therefore at the expense of the social whole. ${ }^{92}$ This relates back once more to the issue of charity, because, as numerous scholars have shown, charity in the middle ages was not understood primarily as a unilateral donation to those in need, where the latter is paradigmatically the stranger, as in the modern conception, but as a kind of social bond which knit society together - a state of relation, in

\footnotetext{
${ }^{88}$ Tan charts how ecclesiastical groups would often set up trusts for the poor to try and alleviate this danger, such that the poor "would no longer be oppressed or devoured by usurers"; "An Empty Shell?" (n. 12 above) 191.

${ }^{89}$ Cited in Noonan, Scholastic Analysis Of Usury (n. 3 above) 163. Social arguments of this sort have a rich heritage in the church fathers. For example, Gregory of Nyssa: "If there were not such a great multitude of usurers there would not be such a crowd of poor people"; cited in Maloney, "The Teaching Of The Church Fathers On Usury" (n. 5 above) 250. Bernadino lived from 1380-1444, and therefore could not have been a source for Dante. I include this quotation as illustrative of an argument nevertheless in evidence well before Bernadino, in earlier scholastic thinking.

${ }^{90}$ Joseph Finkelstein and Alfred L. Thimm, Economists And Society: The Development Of Economic Thought From Aquinas To Keynes (London 1983) 5.

${ }^{91}$ Charles Taylor, A Secular Age (Cambridge, MA 2007) 45, passim.

${ }^{92}$ In so doing, they also distort what medieval theology took to be the providential distribution of wealth.
} 
other words. ${ }^{93}$ To act in charity, therefore, "meant forging or restoring bonds of mutuality between donor and recipient ... [where] the neighbor ... is paradigmatically one's kin." ${ }^{, 4}$ Insofar as usurious lending was seen to embody a coercive and exploitative relation between rich and poor, it so compromised the social bond of charity that constituted the basic principle of unity and cohesion in medieval Christian society.

As this implies, finally, the social critique of usury cannot be understood apart from the virtues, especially charity as just outlined, and also the vices, particularly avarice. ${ }^{95}$ According to Aquinas, as an expression of avarice, usurious lending evidences "a certain defect in regard to the dispensing of wealth and a certain excess in regard to its acquisition and retention because of an excessive love of money." ${ }^{, 96}$ Not only does avarice of this sort contravene charity, but also the virtues of justice and liberality, both of which are social in nature. ${ }^{97}$ In other words, avarice is a vice with expressly social implications. That usurious lending was associated with it further evidences the manner in which the scholastics understood usury to be a sin of similar social consequence.

It is likely that Dante will have been very much aware of the socially exploitative nature of usury, as Catto notes how many wealthy Florentine banking families built their fortunes "on the ... business of lending money to small farmers of the contado or rural communes struggling to pay their taxes. ${ }^{, 98}$ Nevertheless, Dante places the avaricious (that is, the hoarders) well above the usurers, among the sins of incontinence. ${ }^{99}$ Moreover, as noted above, Triolo claims that Dante's decision to frame usury as a sin against art and nature means he forgoes the opportunity to frame it socially as a sin against one's neighbor. ${ }^{100}$ Two aspects of

\footnotetext{
93 "Charity ... meant the state of Christian love that one was in or out of regarding one's fellows; on occasion or body of people seeking to embody that state ..."; John Bossy, Christianity In The West: 1400-1700 (Oxford 1985) 168.

${ }^{94}$ John Milbank, "The Invocation Of Clio: A Response," Journal Of Religious Ethics 33.1 (2005) 23. See also, and preeminently, Bossy on charity, kinship and the "social miracle": Bossy, Christianity In The West (n. 93 above) 57-75, 146-150.

${ }^{95}$ Long, "Usury: Avarice As A Capital Vice" (n. 58 above) 149-157; cf. Aristotle, $\mathrm{Ni}$ comachean Ethics (n. 32 above) IV:1122a.

${ }^{96}$ Aquinas, De Malo (n. 87 above) XIII.1.7.

${ }^{97}$ Ibid. XIII.1.

${ }^{98}$ Catto, "Florence, Tuscany And The World Of Dante" (n. 22 above) 7.

${ }^{99}$ Dante, Inferno (n. 24 above) VII:25ff, 48.

${ }^{100}$ Triolo, "Canto XI" (n. 9 above) 155.
} 
Dante's treatment point firmly against this conclusion, however, and suggest on the contrary that he draws as much on the scholastic socially-based argument against usury, as he does the arguments from money and labor.

While Dante places the avaricious in circle four, he draws a connection between them and the usurers, firstly, by portraying the members of both groups as physically unrecognisable. ${ }^{101}$ The hoarders are "harder to distinguish" due to their "undistinguished" lives, ${ }^{102}$ and the usurers are only identifiable by the family crests on their moneypouches. This anonymity itself is a representation of the socially destructive nature of these sins, as Rossetti explains, “... made in some way invisible or unrecognisable, [the sinners] are cut off from society." ${ }^{" 103}$ Flouting their social obligations on earth, in hell they lack the individuality necessary to be socially known. Dante clearly means to draw attention to the avaricious nature of usury by associating the two groups in this way, and this is further emphasized, second of all, by the usurer's apparent fixation with their money-pouches, on which "par che'l loro occhio si pasca" (they seemed to feast their eyes). ${ }^{104}$ This latter is an effective representation of avarice - that "excessive love of money" described by Aquinas (above) - conveying clearly the usurers' all-consuming obsession with their own wealth, which leads them to disregard their social obligations in favor of personal gain. ${ }^{105}$

The second aspect of Dante's treatment of usury which evinces its social dimension is its ambiguous relation with fraud. For Rossetti, the mere location of the usurers at the far edge of circle seven and close to the void leading to circle eight is enough to ascribe usury with a "quasifraudulent" character. ${ }^{106}$ Canto XVII provides further evidence to this effect. It recounts Virgil and the Pilgrim's passage down to the eighth

\footnotetext{
${ }^{101}$ Dante, Inferno (n. 24 above) VII:49-54, XVII:52-57.

${ }^{102}$ Musa's rendering of "la sconoscente vita che i fé sozzi / ad ogne conoscenza or li fa bruni"; ibid. VII:53-54.

${ }^{103}$ Rossetti, The Shadow Of Dante (n. 57 above) 50. Other misusers of money are also physically unidentifiable in this way, for example, the simoniacs in canto XIX, of whom the only part visible is their feet. Presumably they too, in their own way, are guilty of avarice.

${ }^{104}$ Dante, Inferno (n. 24 above) XVII:57. In looking down, of course, the usurers are also unable to see those around them, which along with their anonymity, further emphasizes their social isolation.

${ }^{105}$ Correspondingly, money is presumably the "something else" in which the usurer is said to invest his hope in ibid. XI:111.

${ }^{106}$ Rosetti, The Shadow Of Dante (n. 57 above) 56.
} 
circle on the back of the monster Geryon, and the presence of the beast, who symbolizes fraud, overshadows the entire canto, including Dante's encounter with the usurers. It is only when Dante and his guide make their way down to Geryon that the usurers are even spotted, almost coincidentally, crouching at the edge of the abyss. ${ }^{107}$ Virgil then instructs Dante to survey the usurers in their torment, but even while the narrative follows the Pilgrim, the reader is aware that Virgil is in the meantime negotiating with the beast. ${ }^{108}$ Thus, in Geryon, whose body is itself spread awkwardly between the two circles, ${ }^{109}$ fraud maintains a lingering and ambiguous presence over the entire proceedings with the usurers, something which Ferrante notes "is reasonably taken to mean that he implies the fraudulent aspects of usury." 110 Thus, Dante here makes usury the common factor between the sins of violence and fraud, just as he made anger the common factor between the sins of incontinence and violence in canto VIII. ${ }^{111}$

That Dante depicts usury as quasi-fraudulent is significant, for our purposes, because of how he presents fraud as an inherently anti-social sin. For Dante, violence and fraud are both sins of malice, but fraud is lower down in hell because it destroys "lo vinco d'amor che fa natura" (the bond of love that nature gives to man). ${ }^{112}$ Dante is here suggesting that fraudulent practices are socially ruinous because they undermine this natural bond of love (the state of charity) between people, thereby implying a social philosophy which correlates clearly with the wider

${ }^{107}$ Dante, Inferno (n. 24 above) XVII:34-36.

${ }^{108}$ Ibid. XVII:41-42. Note Musa's translation, “... I shall speak to this one / and ask him for the loan of his strong back" (emphasis mine).

${ }^{109}$ His body is perched on the edge of circle seven while his tale swishes in the central void; ibid. XVII:25-27. Cf. Cherchi, "Geryon's Downward Flight" (n. 7 above) 229.

${ }^{110}$ Ferrante, Political Vision (n. 1 above) 344.

${ }^{111}$ Dante, Inferno (n. 24 above) 31-81. Virgil and the Pilgrim cross from incontinence to violence via the Styx, the river of the wrathful. This was the last time, incidentally, that the two were separated, again so Virgil could negotiate their passage. That Dante correlates usury with fraud in this way is a traditional interpretation. Cherchi, "Geryon's Downward Flight" (n. 7 above) 226ff; cf. Musa, "Introduction, Notes And Commentary" (n. 29 above) 228 .

${ }^{112}$ Dante, Inferno (n. 24 above) XI:55-56, 62-63. Fraud is therefore a vice which belongs peculiarly to man, and which as a result God hates more than the sins of violence, according to Dante; ibid. XI:22-27. Cf. Triolo, "Canto XI" (n. 9 above) 151ff. Dante seems to get the distinction between violence and fraud from Cicero; ibid. 152. He then makes a further distinction between fraud which undermines the natural bond between men and that which subverts "quel ch'è poi aggiunto, / ci che la fede spezïal si cria" (that extra bond / between men which creates a special trust); Dante, Inferno (n. 24 above) XI:62-63. Violators of this special bond, the treacherous, are punished in circle nine. 
medieval vision of society as an harmonious whole, grounded in charity, discussed above. In associating usury with fraud Dante is acknowledging how usury subverts this vision of society, as the scholastics frequently maintained. Ferrante is probably correct to argue that Dante places usury in the circle of violence rather than fraud because usury lacks the element of formal deception that characterizes the latter-the borrower of course knows the terms of a usurious contract before signing it. ${ }^{113}$ Fraud, in contrast, always involves explicit deception, whether in word, "thing" (e.g., falsifiers of coins), or deed, and sometimes in all three. ${ }^{114}$ Nevertheless, while usury is not formally deceptive, usurers were, as noted above, deemed to be guilty of a form of coercion, especially when lending to the needy, who have little option but to accept whatever terms are offered them. The scholastics perceived the usurer to be abusing his position of financial power for personal gain and to the detriment of others. Thus, like the fraudulent, the usurer too breaches the 'bond of love' between men, prioritizing individual wealth over the good of the community of which he is part. By ascribing a quasi-fraudulent character to usury, Dante acknowledges that usury is not just violence against God and art, but also against society in general. ${ }^{115}$ In so doing, he again echoes scholastic teaching on the subject.

\subsection{The Social Argument As Unifying FaCtor}

The final point to make is that the money and labor arguments themselves also have a social dimension, and therefore one can regard Dante's treatment of usury as fundamentally held together by its social element. Firstly, money, as a means of exchange, concerns everyday transactions between members of a community. Usurers subvert and curtail the integrity of these transactions by using money illegitimately as a direct means of profit. Secondly, by profiting from the labor of another, the usurer commits a form of theft, and as with all theft, this is socially destructive. ${ }^{116}$ Indeed, beyond that, it also channels wealth disproportionately to certain members of the community and away from

\footnotetext{
${ }^{113}$ Ferrante, Political Vision (n. 1 above) 362.

${ }^{114}$ Ibid. $344-356$.

${ }^{115}$ Rossetti, Shadow Of Dante (n. 57 above) 50.

${ }^{116}$ Cf. Albertus Magnus: "[The borrower] by hard labor has acquired something as profit on which he could live, and this the usurer, suffering no distress, spending no labor, fearing no loss of capital by misfortune, takes away, and through the distress and labor and changing luck of his neighbour collects and acquires riches for himself"; cited in Langholm, Economics In The Medieval Schools (n. 3 above) 197.
} 
others: more specifically, towards those who already have the financial liquidity to lend, and away from those who don't. It is therefore a means of making the already rich richer and the already poor poorer: a motor for inequality, and an artificial subversion of what Dante would have considered the providential distribution of wealth. ${ }^{117}$ Taking this into account, it is perhaps not surprising to find that Dante's treatment of usury in the Inferno is constantly suggestive of this social factor. It is depicted, for instance, in the unrecognizability, or "facelessness," of the usurers; their avaricious obsession with their money pouches, which causes them to look only down, rather than to those around them; the connection drawn between usury and the socially atomizing sins of fraud; as well as the usurer's lack of movement (except in relieving their own discomfort), and their general silence (except for one character who speaks rudely and slanderously, and to whom Dante fails to respond).

Ferrante has argued persuasively that Dante does not take an unnecessarily immoderate position on trade and commerce for his time. ${ }^{118} \mathrm{He}$ does, however, hold that the concern for profit and commercial success must be subordinate to the common good. ${ }^{119}$ Bad commercial practice is therefore that which prioritizes individual interest over those of the community. In this sense, to quote John Ruskin, like all forms of "bad commerce" in the Inferno, usury has the social outcome of making "all men strangers"; ${ }^{120}$ that is, it serves to fracture and fragment the bonds of community and of charity. This stands in stark contrast to Dante's vision of the charitable society envisaged, for instance, in canto XV of the Purgatorio. Here, with each love "transaction" (in neo-platonic fashion) "più vi s'ama / e come specchio l'uno a l'altro rende" (love grows more / each soul a mirror mutually mirroring). ${ }^{121}$ In other words, the more that is given, the more each one is said to possess. One good that is shared, "in più posseditor, faccia più ricchi / di sé, che se da pochi è posseduto" [makes(s) all those who possess it wealthier / than if

\footnotetext{
${ }^{117}$ Ferrante, Political Vision (n. 1 above) 341.

${ }^{118}$ Ibid. 316, 324.

${ }^{119}$ Ibid. 324-325.

${ }^{120}$ Cited in Alison Milbank, Dante And The Victorians (Manchester 1998) 32. Dante was seemingly a substantial influence on Ruskin's own critique of usury; Wilmer (n. 45 above) 291, 326.

${ }^{121}$ Dante, Purgatorio (n. 50 above) XV:75. Cf: "E quanta gente più là sù s'intende, / più v'è da bene amare, e più vi s'ama" (And the more souls there above who are in love / the more there are worth loving). Ibid. XV:73-74; cf. XV:55-57.
} 
it were possessed by just a few." ${ }^{122}$ Such an economic vision defies the logic of the usurer, who lends only to receive back more for himself, rather than to enhance the common good. It reveals an economic outlook untainted by envy and "fear of loss"- that is, by logics of scarcity - and rooted instead in an understanding of the plenitude of charity, a social gift which, each time it is given away, is yet received back, paradoxically, in greater measure, thereby increasing the common wealth. ${ }^{123}$ In this context, far from making all men strangers, each "transaction" contributes to the making of all men into brothers, and all women into sisters.

\section{CONCLUSION}

To conclude, writing against a complex economic background, and in the knowledge of widespread usurious practice in medieval Florence, Dante draws copiously from the well of scholastic teaching on usury in his Inferno. Several aspects of his overall portrayal of usury correlate closely with well-documented scholastic argumentation on that subject. First, Dante relates usury with the sins of blasphemy and sodomy by way of comparison and contrast. Where sodomy makes that which is productive (sex) sterile, usury makes that which is sterile (money) artificially productive; where blasphemy subverts the doxological end of language, usury subverts the proper telos of money, which is to facilitate exchange. This is an effective re-rendering of a critique of usury common in medieval scholastic economics, grounded in their understanding of the nature of money, which has roots reaching back to Aristotle. Secondly, while Dante does not draw on a further scholastic critique of usury grounded in concepts of time, he does adapt their "labor argument," which repudiates usury on the grounds that the usurer does not "work for his bread," preferring to live off the labor and industry of another, namely the borrower. In canto XI, Dante leans quite explicitly on this argument, using it to label usury (via Aristotle) "violence against art." Thirdly, Dante makes use of a more general social critique of usury also common in scholastic political and economic theory. He does this first by linking the usurers with the avaricious of canto VII through his description of the usurers' posture, and secondly by portraying usury in a quasi-fraudulent light. Both avarice and fraud

\footnotetext{
${ }^{122}$ Ibid. XV:62-63.

${ }^{123}$ Ibid. XV:49-57.
} 
are distinctively social sins in the scholastic analysis, that is, sins deemed to have deeply destructive social implications; by associating usury with these two, Dante is clearly implying the same can be said of usury. This latter point is further emphasized by noting that the first two arguments against usury utilized by Dante, from money and labor, themselves have social dimensions. It can therefore be suggested that the social aspects of Dante's critique of usury undergird his entire treatment, thereby tying in with his wider critique of "bad commerce" throughout the Inferno. Not only does usury subvert the nature of money and the relation between labor and just reward, but for Dante it is also socially ruinous, especially in a society which perceives itself as an harmonious whole. By presenting usury in this comprehensive light, Dante re-renders to great effect key elements of the scholastic critique of usury, offering a narrative-poetic depiction of that sin which is in substantial continuity with wider scholastic teaching. An awareness of this helps to better situate the Inferno within its historical and cultural context, and further illuminates the economic and political dimensions of this famous work. 